\title{
The Flood Analysis of Karadere Stream in the Mustafakemalpaşa District of Bursa Province and Determination of Its Effect on the Sünlük District Settlement
}

\author{
${ }^{1 *}$ Burak Boz, ${ }^{2}$ Egemen Aras, and ${ }^{3}$ Babak Vaheddoost \\ Department of Civil Engineering, Bursa Technical University, Bursa-Turkey \\ ${ }^{1}$ MSc Student, e-mail: burak_boz@windowslive.com \\ ${ }^{2}$ Prof. Dr. , e-mail: egemen.aras@btu.edu.tr \\ ${ }^{3}$ Dr. , e-mail: babak.vaheddoost@btu.edu.tr
}

\begin{abstract}
Floods shows an increase both in number and in terms of damages they cause in tropical climates as well as in Turkey which is not located in tropical region. With the increasing population density and unplanned urbanization, life and property losses become inevitable as a result of these floods. In this study, the flood analysis of the section between the beginning and the end of the Sünlük District settlement located on the border of Karadere Stream in the Mustafakemalpaşa District of Bursa Province was assessed. The planning works of the Sünlük Dam on the Karadere Stream, which is intended to provide drinking water and industrial water to the Mustafakemalpaşa and Karacabey Districts of Bursa Province, are continuing by the $1^{\text {st }}$ Regional Directorate of State Hydraulic Works of Turkey (DSI). Flood areas were determined with the help of the HEC-RAS (Hydrologic Engineering Centers River Analysis System) software and applying the Q1000, Q10000 and QMMF (probable maximum flood) flood return period flow rates at the Karadere Stream which obtained from the dam planning studies. It was concluded that the damage caused by QMMF can reach up to 1000000 TL once flood occur.
\end{abstract}

Key Words: HEC-RAS, flood analysis, Karadere Stream, Mustafakemalpaşa District

\footnotetext{
* Corresponding author: Burak BOZ. Address: Faculty of Engineering, Department of Civil Engineering Bursa Technical University, 16290, Bursa TURKEY. E-mail address: burak_boz@windowslive.com.tr, Phone: $\mathbf{+ 9 0 5 3 3 6 2 1 9 1 6 2}$
}

\section{1.İntroduction}

Flood is one of the main phenomena which treats settlements, agricultural and/or nonagricultural lands while the water in river streams overflow from its natural bed. According to State Hydraulic Works of Turkey (DSI) data, 695 flood events occurred between 1975 and 2010 in Turkey. As a result of these floods, 634 lives were lost and 810000 hectares of agricultural land were exposed to flood. The total damage of floods to the country's economy is approximately 3717000 dollars [1]. Several efforts have been made to reduce the construction of dams, ponds and flood remediation structures. However, these studies found to be insufficient in some regions due to reasons such as global climate change, unplanned 
urbanization and unbalanced demographic structure. In this respect, Figure 1 shows the number of floods that occurred between 1940 and 2010 in Turkey [2]. Therefore, it is inevitable to study flood events while considering their different aspects. The experiences gained so far showed that the floods occurred as a result of irregular and distorted urbanization in the areas where there is a possibility of flooding in or around the river bed rather than heavy rainfall. There are different classifications and definitions for floods in the literature.

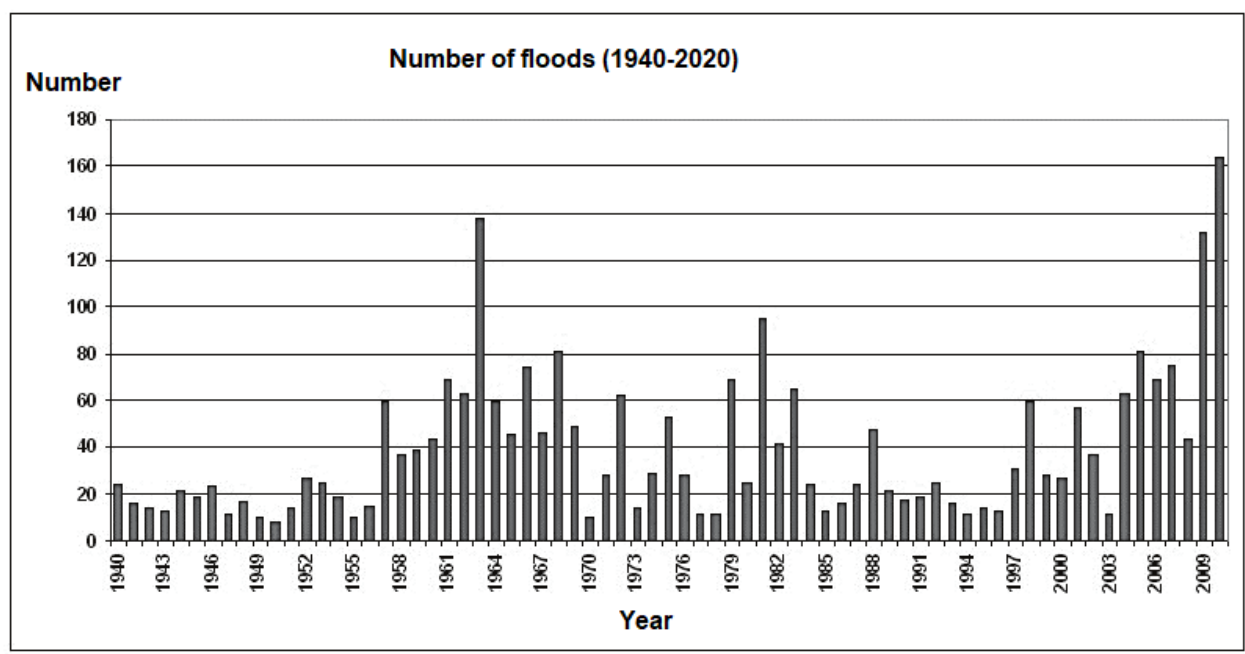

Figure 1. Number of flood that occurred between the years of 1940-2010 in Turkey (MGM 2014)

According to the World Meteorological Organization (WMO), floods in their most general form can be classified as [3],

1. Sudden floods,

2. River floods,

3. Coastal floods,

4. City floods,

5. Floods caused by snowmelt

6. Floods caused by ice and rubble movements

and this can be used in definition of the floods and their consequences in regions.

So far, River floods are the most frequent events in Turkey which catastrophically cause in loss of lives and investments. Hence, in this study, the draw backs of river flood in Karadere Stream is investigated using HEC-RAS software. For this, the maximum historical discharges with return period of 1000 and 10000 years together with probable maximum flood rate were used in the analysis.

\section{Materials and Method}

The study area is the part of the Karadere Stream, which is located about $10 \mathrm{~km}$ to the south of the Mustafakemalpaşa District (in center of Bursa-Turkey), between the beginning and the end of the settlement in Sünlük District (Figure 2).

Sünlük District is a settlement with a population of 454, connected to the Mustafakemalpaşa District. There are fertile agricultural lands that can be irrigated around the quarter settlement area. While the flood occurs, these are can be covered by the water and life and economical loss 
may emerge. Thereby, flood scenarios with their possible consequences should be developed and assessed for the region.

This include but not limited to statistical evaluation of the hydrographs, studying return period of the floods, hydraulic modeling, and risk evaluation. Thus, in the following sections, the methodology used in the modeling the hydraulic behavior of the flood with the allocated hydrographs is detailed.

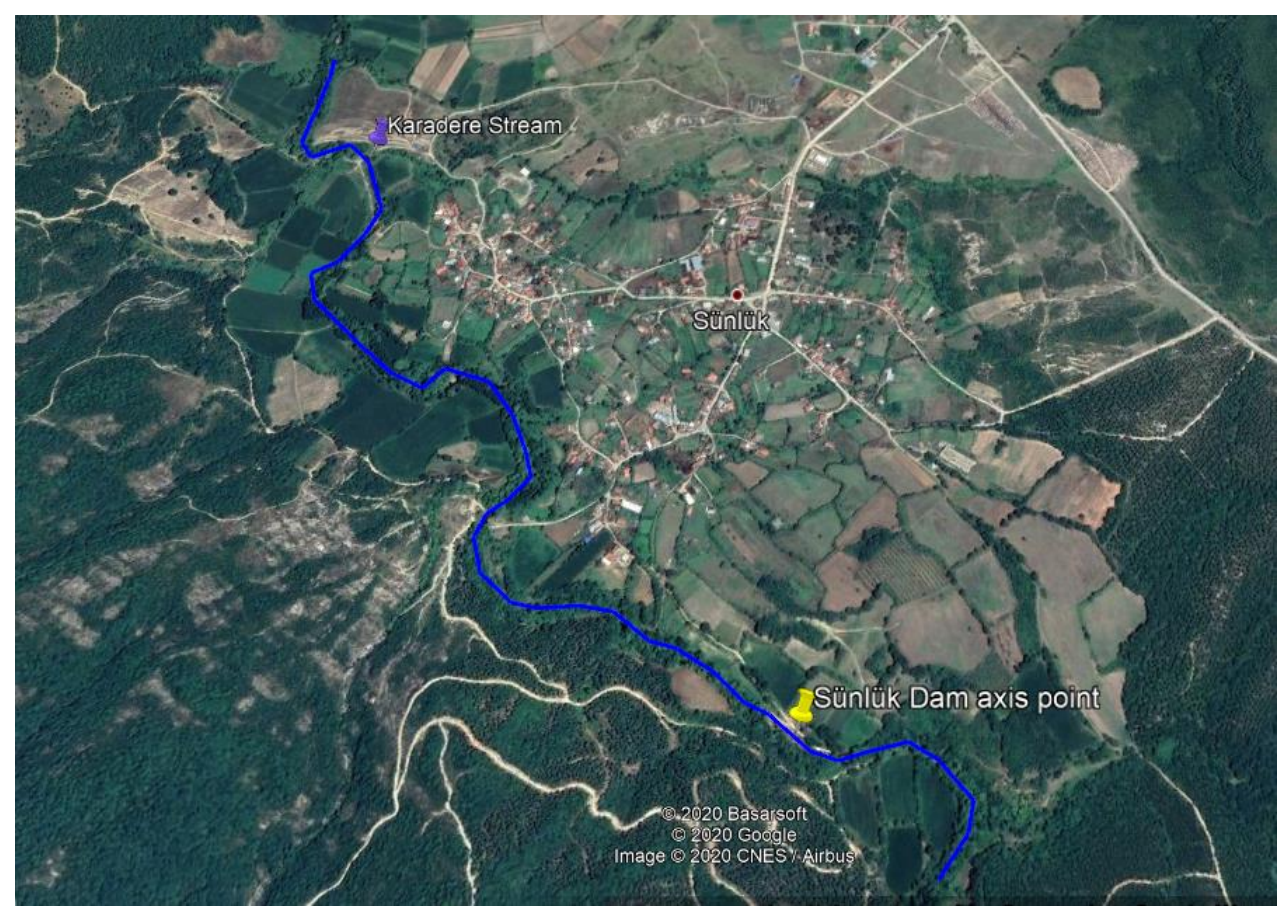

Figure 2. Flood Analysis Study Area

\subsection{Data}

Flood recurrence flow rates of Karadere Stream used in flood analysis were obtained from DSI $1^{\text {st }}$ Regional Directorate (Table 1) [4].

Data were calculated by the relevant Meteorology Engineers within the scope of the planning studies of the Sünlük Dam planned to be built on the Karadere Stream.

As the map data for the flood analysis carried out in this study, a map of the region was created by means of the Global Mapper program with the help of the points obtained from the vector maps of the region and the TIF 
file of the study area was obtained from this map (Figure 3).

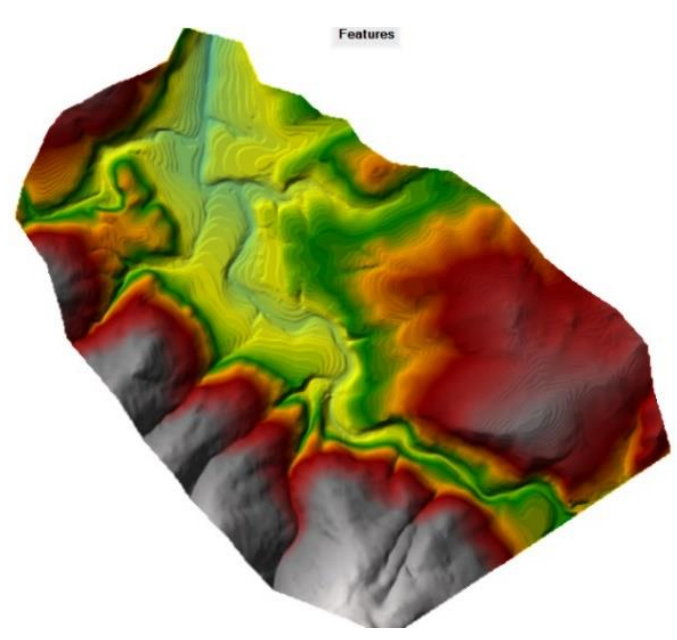

Figure 3. TIF map used in flood analysis

Table 1. Flood Recurrence flow rates

\begin{tabular}{|r|r|r|r|}
\hline $\begin{array}{r}\text { T } \\
\text { (Hour) }\end{array}$ & $\begin{array}{r}\text { Q1000 } \\
\text { (m3/s) }\end{array}$ & $\begin{array}{r}\text { Q10 000 } \\
\text { (m3/s) }\end{array}$ & $\begin{array}{r}\text { QMMF } \\
\text { (m3/s) }\end{array}$ \\
\hline 0.0 & 5.29 & 5.29 & 6.30 \\
\hline 0.5 & 12.69 & 15.61 & 26.51 \\
\hline 1.0 & 31.86 & 42.35 & 78.86 \\
\hline 1.5 & 63.46 & 86.42 & 165.16 \\
\hline 2.0 & 102.85 & 141.35 & 272.71 \\
\hline 2.5 & 140.02 & 193.05 & 371.24 \\
\hline 3.0 & 165.09 & 227.64 & 431.97 \\
\hline 3.5 & 180.78 & 248.91 & 462.09 \\
\hline 4.0 & 178.57 & 245.06 & 440.20 \\
\hline 4.5 & 171.86 & 235.04 & 408.13 \\
\hline 5.0 & 156.58 & 213.40 & 359.44 \\
\hline 5.5 & 139.42 & 189.41 & 311.44 \\
\hline 6.0 & 117.69 & 159.45 & 259.42 \\
\hline 6.5 & 97.93 & 132.29 & 213.75 \\
\hline 7.0 & 79.37 & 106.84 & 172.06 \\
\hline 7.5 & 64.62 & 86.62 & 139.15 \\
\hline 8.0 & 52.43 & 69.91 & 111.65 \\
\hline 8.5 & 42.64 & 56.48 & 89.50 \\
\hline 9.0 & 35.07 & 46.10 & 72.65 \\
\hline 9.5 & 29.37 & 38.30 & 60.03 \\
\hline 10.0 & 24.76 & 31.99 & 50.00 \\
\hline 10.5 & 20.81 & 26.58 & 41.30 \\
\hline 11.0 & 17.45 & 21.97 & 33.62 \\
\hline 11.5 & 15.09 & 18.73 & 28.27 \\
\hline 12.0 & 13.42 & 16.43 & 24.50 \\
\hline 12.5 & 11.81 & 14.23 & 20.86 \\
\hline 13.0 & 10.37 & 12.26 & 17.69 \\
\hline 13.5 & 9.44 & 10.98 & 15.64 \\
\hline 14.0 & 8.66 & 9.92 & 13.87 \\
\hline 14.5 & 7.93 & 8.90 & 12.20 \\
\hline 15.0 & 7.41 & 8.20 & 11.07 \\
\hline 15.5 & 7.00 & 7.64 & 10.12 \\
\hline 16.0 & 6.59 & 7.07 & 9.17 \\
\hline 16.5 & 5.82 & 6.01 & 7.23 \\
\hline 17.0 & 5.73 & 5.88 & 7.07 \\
\hline 17.63 & 5.53 & 5.62 & 6.73 \\
\hline & & 5.29 & 6.30 \\
\hline
\end{tabular}

\subsection{Flood Analysis}

While performing flood analysis in Karadere Creek, at first, TIF map of the study area was created thanks to the Global Mapper program. Afterward, with the help of the HEC-RAS program, where the flood analysis was made, the geometric conditions, including the stream line, the coastal line of the stream and the possible lines that the flood could reach, were determined on the map and also on the satellite view (Figure 4 and Figure 5). 
After determining the geometric conditions, an unsteady flow analysis was performed for each recurrence flow rate by entering Q1000, Q10 000 and QMMF (probable maximum flood) flood recurrence flow rates of the Karadere Stream respectively. As a result of the analysis, the maximum spreading area of the flood that occurred according to each recurrence flow rate was determined and the material and moral effect (such as possible loss of life) of each flood case on the settlement and agricultural lands of the Sünlük District was examined and the results were compared.

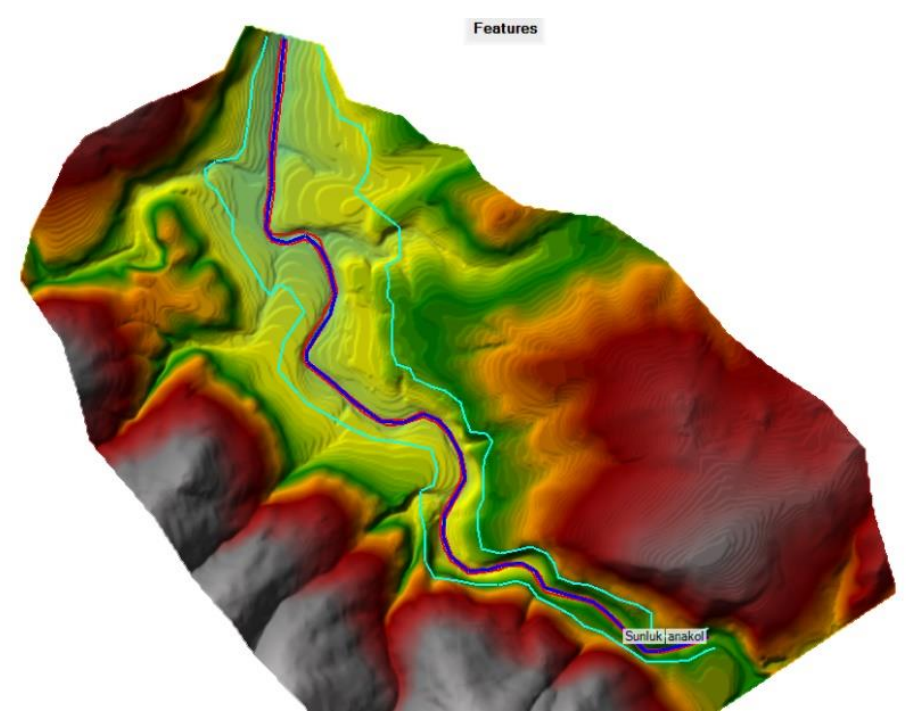

Figure 4. Representation of geometric conditions in TIF map (Blue line: Karadere Stream; Red lines: coastal lines of the stream; Green lines: potential areas for flooding)

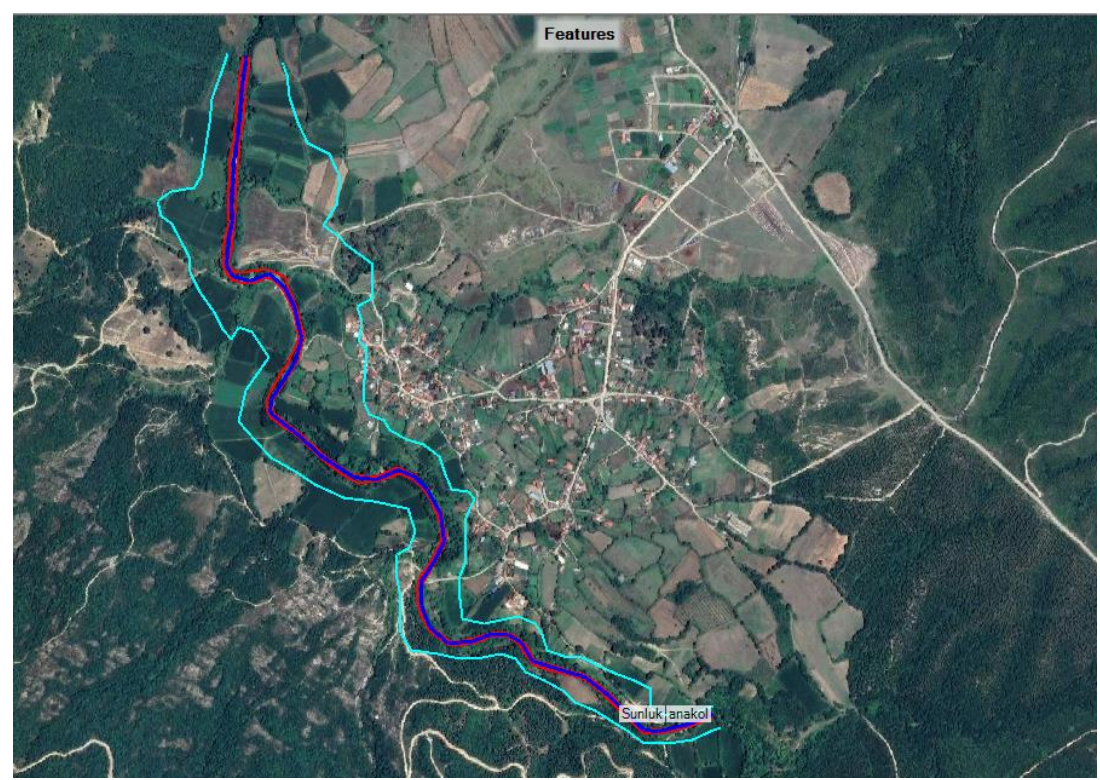

Figure 5. Geometric conditions in satellite view (Blue line: Karadere Stream; Red lines: coastal lines of the stream; Green lines: potential areas for flooding) 


\section{Results and Conclusion}

According to the results of flood analysis made according to each recurrence flow rate, the maximum spread areas of the flood on the satellite view in the region are shown in Figure 6 for Q1000 flow rate, Figure 7 for Q10000 flow rate, and Figure 8 for Q MMF flow. As a result of the analysis, it was observed that no houses from the Sünlük District settled area remained in the flood area considering all three flood cases. Also, it was accepted that there would be no loss of life in the floods.

On the other hand, it has been observed that for each flood situation, different sized agricultural lands, especially around the stream bed, remain in the flood zone. The size of these agricultural lands affected by the flood has been calculated approximately and the annual agricultural income that cannot be obtained from these lands as a result of the flood has been accepted as the material damage of the flood. The material and moral damage that occurred as a result of floods is shown in Table 2.

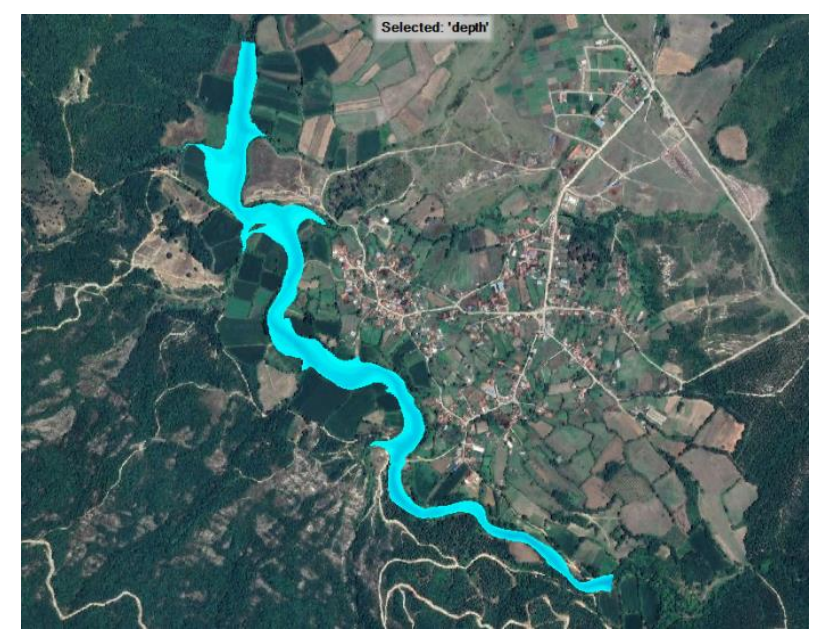

Figure 6. Maximum spreading area of the flood for Q1000 recurring flow rate

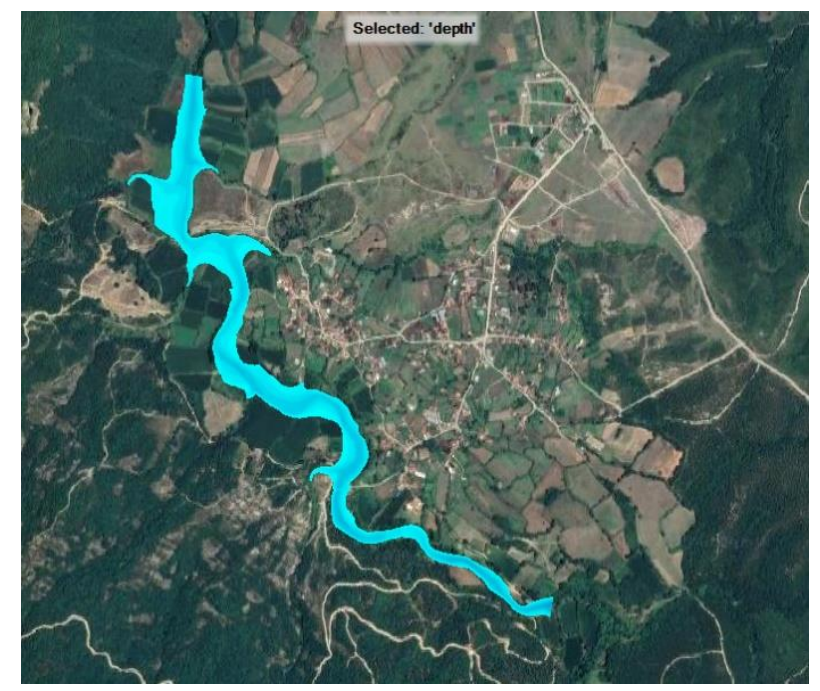

Figure 7. Maximum spreading area of the flood for Q10000 recurring flow rate 


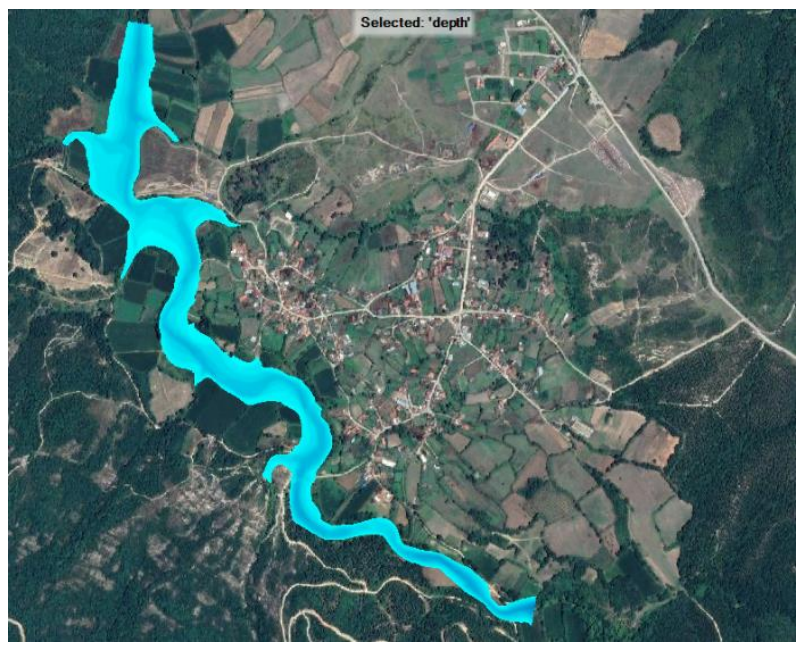

Figure 8. Maximum spreading area of the flood for QMMF recurring flow rate

Table 2. Determination of material and moral damage related to floods that occur as a result of analyzes made with each flood recurrence flow.

\begin{tabular}{|l|c|c|r|r|}
\hline $\begin{array}{c}\text { Flow } \\
(\mathrm{m} 3 / \mathrm{s})\end{array}$ & $\begin{array}{c}\text { House left } \\
\text { in the } \\
\text { flood area } \\
\text { (number) }\end{array}$ & $\begin{array}{c}\text { Possible } \\
\text { loss of life } \\
\text { (number of } \\
\text { people) }\end{array}$ & $\begin{array}{c}\text { Agricultural } \\
\text { land left in } \\
\text { thlood area } \\
\text { (m2) }\end{array}$ & $\begin{array}{c}\text { Flood } \\
\text { demage cost } \\
\text { (Turkish } \\
\text { Liras) }\end{array}$ \\
\hline Q1000 & - & - & 24,900 & 448,200 \\
\hline Q10 000 & - & - & 38,100 & 685,800 \\
\hline Q MMF & - & - & 59,700 & $1,074,600$ \\
\hline
\end{tabular}

\section{References}

[1] Altundal,M. (2010). Taşkınların Ekonomik Analizi. http://www.dsi.gov.tr/docs/sempozyumlar/54task\%C4\%B1nlar\%C4\%B1nekonom\%C4\%B1k-boyutu-maltundal.pdf?sfvrsn=2, (19.091.2014).

[2] Efe H., Önen F. (2015). Batman Çayı'nın taşkın analizinin HEC-RAS programıyla yapılması.

[3] https://insapedia.com/taskin-nedir-taskin-nedenleri-turleri-ve-olusumu/

[4] DSİ (2020).Sünlük Barajı Planlama Raporu çalışmaları, Bursa. 